\title{
CLASTIC SEDIMENTS IN CAVES - IMPERFECT RECORDERS OF PROCESSES IN KARST
}

\author{
KLASTIČNI SEDIMENTI V JAMAH - NEPOPOLNI ZAPIS \\ KRAŠKIH PROCESOV
}

\author{
Ira D. SASOWSKY ${ }^{1}$
}

\begin{abstract}
UDC 552.517:551.7

Ira D. Sasowsky: Clastic sediments in caves - imperfect recorders of processes in karst

Clastic sediments have played an important role in deciphering geologic history and processes since the inception of the discipline. Early studies of caves applied stratigraphic principles to karst deposits. The majority of cave deposits are breakdown and alluvium. The alluvial materials have been successfully investigated to determine ages of caves, landscape evolution, paleoenvironmental conditions, and paleobiota. Rapid stage changes and the possibility of pipe-full flow make cave deposits different than surface deposits. This and other factors present difficulties with interpreting the cave record, but extended preservation is afforded by the "roofing" of deposits. Dating by magnetism or isotopes has been successful in many locations. Caves can be expected to persist for $10 \mathrm{Ma}$ in a single erosive cycle; most cave sediments should be no older than this.
\end{abstract}

Key words: clastic sediments, paleoclimate, sedimentology, stratigraphy, dating.
Izvleček

UDK 552.517:551.7

Ira D. Sasowsky Klastični sedimenti v jamah - nepopolni zapis kraških procesov

Že od nekdaj so klastični sedimenti pomembno orodje pri razbiranju geološke zgodovine. V zgodnjih študijah so uporabili načela stratigrafije tudi pri raziskovanju jamskih sedimentov . Glavnino jamskih sedimentov sestavljajo podori in aluvij. Raziskave aluvija so se uspešno izkazale pri dataciji jam, določanju razvoja površja, paleookolja in paleontologije. Zaradi možnega tlačnega toka in hitrih sprememb stanj, so jamski sedimenti drugačni od površinskih. To, poleg ostalih dejavnikov, predstavlja težave pri interpretaciji zapisov, ki jih hranijo jame. Po drugi strani pa je obstojnost jamskih sedimentov daljša zaradi zavetja, ki jim ga nudi jama. Po vsem svetu poznamo številne uspešne datacije jamskih sedimentov $\mathrm{z}$ magnetizmom ali izotopi. Jame znotraj erozijskega cikla vzdržijo do10 milijonov let, zato naj jamski sedimenti ne bi bili znatno starejši.

Ključne besede: klastični sedimenti, paleoklima, sedimentologija, stratigrafija, datiranje.

\section{INTRODUCTION}

Geology is undeniably a science of history, and since the earliest practice of the discipline, that history has been revealed in clastic sedimentary deposits. William Smith, for example, created maps of the sedimentary rocks in England in the late 1700's, and established a relative chronology of their deposition using stratigraphic position and fossils. It has been natural, therefore, that karst scientists examine clastic deposits in caves, in order to explore geologic time. In doing so, they are in large part applying the same principles and techniques developed by classical stratigraphers. An early example of this was a study by Kukla and Ložek (1958) examining the processes of cave sediment deposition and preservation. In the present day, work such as that by Granger et al. (2001) and Polyak et. al. (1998) builds upon those classical techniques and applies laboratory methods to develop absolute chronolo-

${ }^{1}$ Office for Terrestrial Records of Environmental Change, Department of Geology and Environmental Science, University of Akron, Akron, $\mathrm{OH}$ 44325-4101, USA.

Received/Prejeto: 24.01.2007 
gies. These chronologies in turn have allowed insight to such processes as river incision, water-table lowering, and landscape/climate linkages.

This paper is a brief evaluation of clastic sediments as they apply to deciphering historical processes and events in karst terrane. Advantages and problems of working with these unique deposits are presented. For purposes of this paper, the "age" of a given cave sediment refers to the time of deposition of the material in the cave.

\section{MATERIALS AND PROCESSES}

The processes that result in clastic sedimentation in caves are quite varied. Reviews and details including classification of deposits are presented in several texts (White, 1988; Ford and Williams, 1989; Sasowsky and Mylroie, 2004). A perspective is given here.

A useful broad-level classification is genetic, and based upon whether the clastic material originated within the cave (autogenic) or was carried in from the surface (allogenic). The former class is mainly bedrock breakdown (incasion), but encompasses fine grained sediments sourced from insoluble residue during phreatic enlargement, collapse of secondary mineralization (speleothems), and so forth. Allogenic sediments include alluvium, windblown material, animal feces, fossil matter, till, etc.

In practice, the most commonly occurring materials by far are bedrock breakdown and alluvium. Consequently, autogenic cave sediments are mainly limestone. Allogenic sediments are usually resistant siliciclastics, because carbonates do not typically persist in the fluvial environment.

There is no satisfying overall term for the clastic deposits found in caves. The word "soil" has been applied to the fine grained deposits, but this is a misnomer by most definitions, and is not recommended. Cave fill and cave earth have also been used. Regolith seems applicable in spirit, but, because this material does not strictly "....form(s) the surface of the land ...." (Jackson, 1997) some may object to such usage.

\section{BREAKDOWN}

The collapse of cave bedrock walls and ceilings results in material that is angular, and ranges in size from sand to boulders. It is possible many times to visually fit larger blocks to their point of origin on the adjacent cave walls and ceilings. The process of breakdown is not a common occurrence on human timescales. Only a few cases of present-day natural failure have been documented. For example, in Mammoth Cave, Kentucky only one large collapse was noted in 189 years of mining and tourism (May et al., 2005). However, on geologic timescales, the proc- ess is pervasive and evident in most caves. Failures occur along existing planes of weakness (joints, faults, bedding planes). Causes of collapse can include removal of underlying support (particularly loss of buoyancy caused by the transition from phreatic to vadose conditions), removal of overlying arch support, cryoclastism (wedging by ice), and secondary mineral wedging (White and White, 2003). Triggering by earthquakes has also been observed, for example in Sistem Zeleške Jame-Karlovica (personal communication, F. Drole). Davies (1951) published an early analysis of expected collapse parameters in the cave environment. This was expanded on by White (1988, p. 232) to evaluate stability of ceilings relative to limestone bed thickness. Greater spans can be maintained by thicker beds. Jameson (1991) provides a comprehensive overview and classification of breakdown.

Breakdown is frequently most prolific at 1 ) the intersections of cave passages, presumably due to the greater span lengths present at such points, and 2) where the cave is close to the surface, due to lack of thinning of the span and resulting decreased competency. In evaluations of causes for passage terminations (White, 1960) it was noted that many cave passages ended in breakdown blockage (referred to by explorers as "terminal breakdown").

Although pervasive, breakdown has not found significant utility for deciphering earth history in karst terranes.

\section{ALLUVIUM}

Alluvium enters caves by sinking stream, and occasionally by colluvial mechanisms. The transport processes are for the most part similar to those in surface channels. The full range of sediment sizes are seen, structures such as cross-bedding and pebble imbrications develop, and cut-and-fill stratigraphy is possible. However, there are two important differences exhibited for stream flow in caves when compared to most surface channels. First, channel width is severely constrained by bedrock walls. This promotes rapid stage increase during flooding, akin to that of slot canyons in surface streams (Fig. 1). Second, 


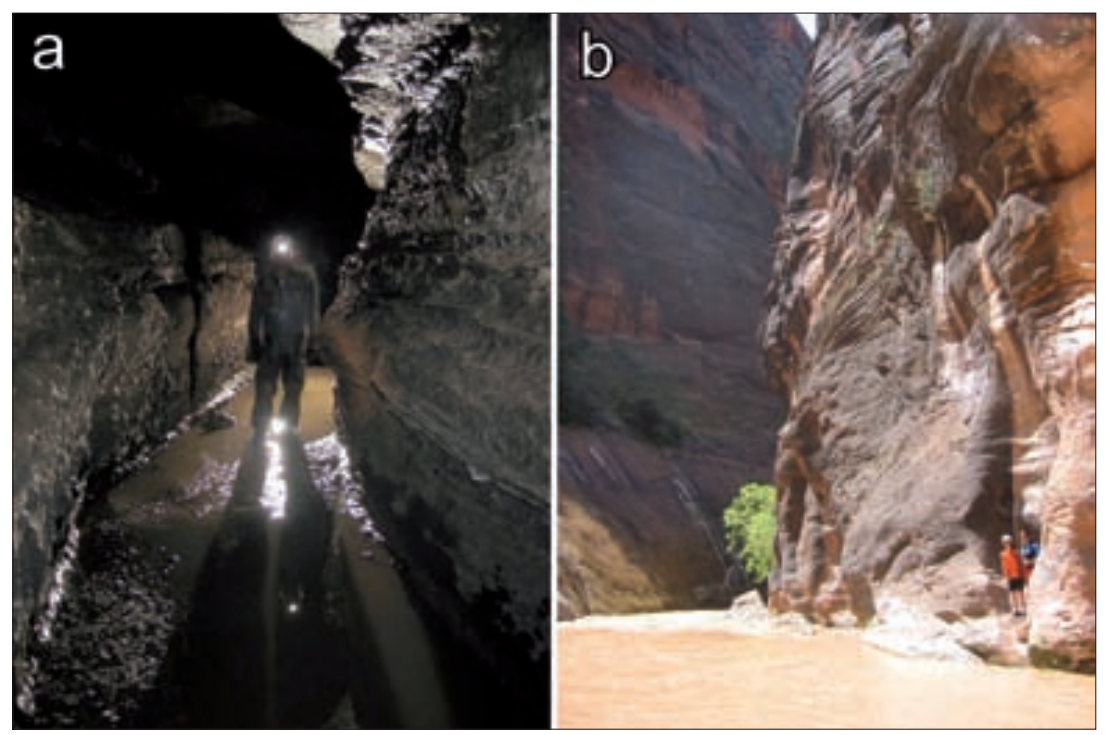

Fig. 1: Subterranean stream channels are typically narrow, and have no floodplain (a). This leads to rapid stage changes. Similar conditions in the surface environment are only seen in slot canyons such as the Virgin River, Utah, USA (b).

because the channel is roofed over, it is possible to have confined (pipe-full) rather than open channel flow. Taken in conjunction, the results of these two conditions are the likelihood of high flow velocities, and the possibility of upwards phreatic flow. A striking example of rapid stage change is seen in Hölloch, Switzerland, where rises of $250 \mathrm{~m}$ in a single flood have been recorded (Wildberger and Preiswerk, 1997; Jeannin, 2001). Cases of phreatic lifts are seen in many cave systems. In Castleguard Cave (Rocky Mountains, Canada) a seasonally active lift of $9 \mathrm{~m}$ is observed (Schroeder and Ford, 1983). In that situation wellrounded cobbles are accumulated at the base, where they reside until communition reduces them sufficiently to allow transport up the lift tube.

The composition of the alluvium reflects the source of the material, as well as some other factors. It is interesting to note that a high proportion of clay sized material found in cave alluvium is actually fine-grained silica, not a clay mineral (White, 1988). The residuum found on the surface of many karst terranes frequently contains high amounts of clay and chert. The clay results from insoluble residues of the weathered limestone. The chert behaves in a very persistent way, being found throughout cave passages.

\section{INFORMATION REVEALED}

In the investigation of clastic sedimentary deposits, either cave related or not, answers are sought to such questions as: How old? What was the paleoenvironment? What was the flow direction? What organisms were present? These in turn allow an understanding of geologic history, environments of deposition, past climates, and potential for sedimentary deposits to act as mineral and fuel reservoirs.

In the case of cave studies, it is primarily the first question which has been addressed. Caves can only be numerically dated by the deposits that they hold, and this age is usually reported as a minimum value. Alluvial materials are considered superior to speleothems in this undertaking, because they are emplaced much earlier in the existence of the cave. Once a date has been obtained, subsequent inferences such as rates of river incision, denudation, and so forth, can then be made based upon the relation of the cave to the landscape. Dating has been accomplished by radiocarbon, magnetism, and cosmogenic isotopes.
Paleoenvironmental information is revealed through studies of sedimentary structures and sequences, as well as via analyses of clay mineralogy and environmental magnetism. Paleohydrology can be deduced using traditional stratigraphic indicators such as cross-bedding, pebble imbrication, etc. Fossil deposits of organisms are actually rather rare within caves - most cave depsits are barren of these materials. Significant deposits are known, though, and many excavations made in caves (particularly in the entrance facies) serve as irreplaceable records of terrestrial fauna. 


\section{LIMITS ON TIMESCALE}

Caves are erosional landforms, which have a limited period of existence. Excluding those caves which have been subjected to burial, this places a practical limit on their duration as potential recorders of nearby processes. In any case, the cave sediments can be no older than the cave they are emplaced in (Sasowsky, 1998). Therefore, the ultimate limit on preservation of sediments within a cave is the persistence (lifetime) of the cave in the environment.

In most limestone terranes epigenetic processes occur, with dissolution taking place both at the surface (forming pavements, dolines, etc.) and in the subsurface (forming caves). As base level lowers, denudation of the upland surfaces is also occurring and uppermost caves are eventually breached and destroyed. In certain settings examples of various states of decay can be seen in the landscape, and the sedimentary fills of breached (unroofed) caves may even be observed (e.g. Šušteršič, 2004). In settings such as the Appalachian Valley and Ridge, hundreds of meters of carbonate have been denuded from anticlinal valleys (White, 1988), and one may imagine extensive systems of caves which have been obliterated with no remaining trace.

Bounds on the expected lifetime of an epigene cave may be evaluated by considering the two main control-

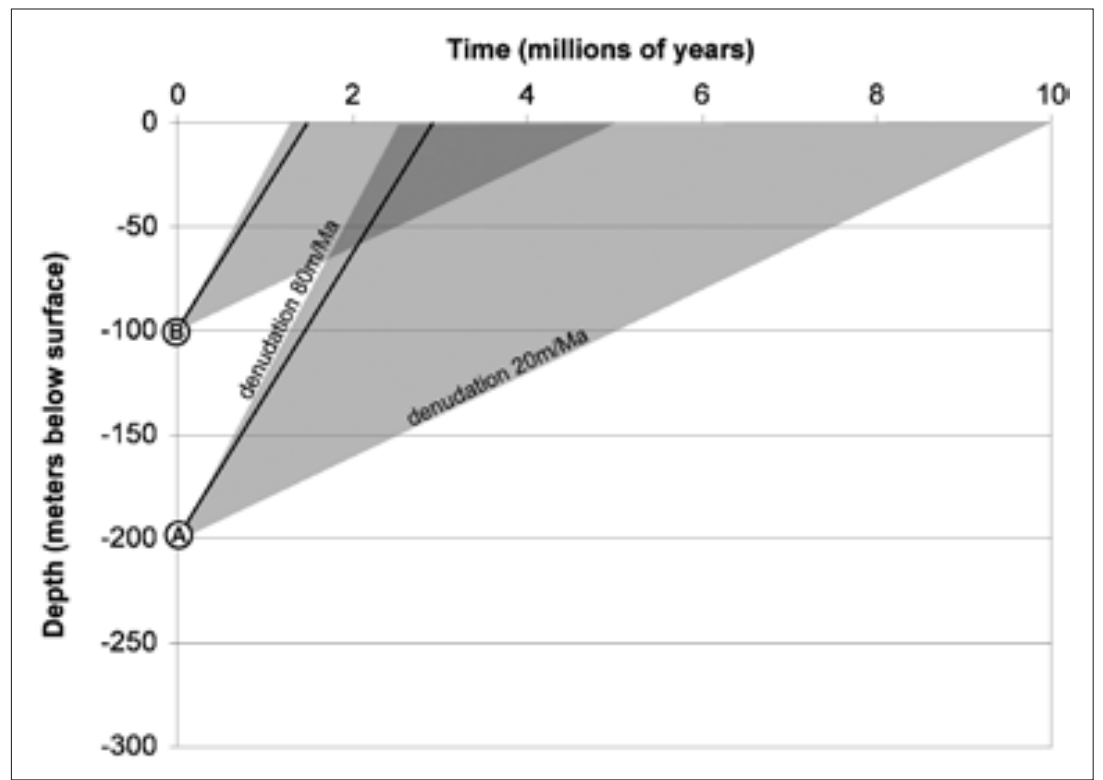

Fig. 2: Theoretical persistence of caves in an erosional environment. The length of time that a given cave will exist depends upon the initial depth of formation (position on $y$-axis) and the denudation rate (slope of line). Gray regions envelope a range of reasonable denudation pathways for two examples. In case A, a cave formed at $200 \mathrm{~m}$ depth, the expected lifetime is 2.5 to $10 \mathrm{Ma}$. For a cave formed at $100 \mathrm{~m}$ depth (case B), the lifetime is reduced to 1.25 to $5 \mathrm{Ma}$. Solid sloping lines are the average denudation rate, $69 \mathrm{~m} / \mathrm{Ma}$, for 33 major drainage basins (calculated from data in Summerfield and Hulton, 1994). ling factors: initial depth of formation and rate of land surface lowering (denudation, Fig. 2). Although caves may form at any depth, a practical limit of $300 \mathrm{~m}$ is reasonable, and the majority of caves are much shallower (Milanovic, 1981). Note that this "depth" is not correlative to the frequently reported mapped depth of caves, which refers to the maximum vertical extent of survey. In the context of the present evaluation, depth is the position below surface (thickness of overlying rock) at a given point in the cave. Denudation rates can be quite variable, and tend to correlate with rainfall (White, 1988, p. 218). Envelopes of expected cave persistence can be constructed (Fig. 2) using these 2 parameters. Based upon this calculation, epigene caves would usually exist in the erosive environment for up to $10 \mathrm{Ma}$.

In practice, dating has not yet resulted in identification of caves this old within the present erosional cycle. Paleomagnetic dating has been used back to $4.4 \mathrm{Ma}$ (Cave of the Winds, Colorado, USA; Luiszer, 1994). Cosmogenic isotope dating has documented cave sediments as old as $5.7( \pm 1.1) \mathrm{Ma}$ (Bone Cave, Tennessee, USA; Anthony and Granger, 2004). The absence of older values may be a consequence of limitations of dating methods, or reflect the relative dearth of older caves in the environment, or both. The challenges of paleomagnetic dating include absence of fine-grained sediments, lack of uninterrupted sedimentation, and uncertainties of correlation with the global magnetic polarity scale. Cosmogenic dating is constrained by the absence of quartzose sediments, uncertainties in parent isotope values, and the cost/effort of analyses.

If consideration is extended beyond the present erosional cycle, filled and buried caves (paleokarst) are found in the rock record. Such materials have been recognized in many places, and the fills described in some detail (e.g. Loucks, 1999). Interest has been strong in the context of exploration for minerals or petroleum. These deposits also represent a potential trove of information on far past hydrologic and environmental conditions because of their capacity to preserve. 


\section{RESOLUTION, CONTINUITY, AND VERACITY}

Stratigraphers have traditionally examined marine or paralic sediments because of their resolution, continuity, and veracity. Compared to terrestrial deposits, marine/ paralic strata are much more laterally and vertically extensive, they are of economic interest, and they potentially function as continuous recorders for long periods of time. Terrestrial deposits are of interest though, particularly because they contain information about the on-continent setting. Within the terrestrial environment lacustrine deposits and fluvial terraces have seen the greatest attention as recorders of Cenozoic paleo-conditions. Lakes probably represent the highest quality records in the terrestrial environment - their environment many times is one of high preservation potential. Lacustrine deposits can be sampled by coring; duplication of cores can serve as a quality control; accumulation rates can be rapid; sediment properties are well tied to local environmental conditions; and spatial variability is usually well understood. Terraces tend to preserve a partial record of the fluvial environment, depending upon regional uplift or down-cutting of the stream.

In comparison, most caves contain spatially irregular deposits that can be affected by factors such as plugging of swallets, extreme flow events, and back-flooding. Hydrologic complexity is common (Bosák et al., 2003), even more so than surface fluvial environments. Analysis of the paleohydrology of the depositional setting through cave passage morphometry is usually necessary, and may be quite time consuming if detailed maps are not available. Stratigraphic sections may be discontinuous, and require compilation. Caves are difficult sampling locations, due to logistics, remoteness, lack of light, and constraints on sampling equipment transport.

Nevertheless, the cave environment is one that provides some advantages in recording the history of a region. The greatest advantage is that of potential preservation. Because caves are "roofed over" deposits are likely to be protected (at least on intermediate time scales), from

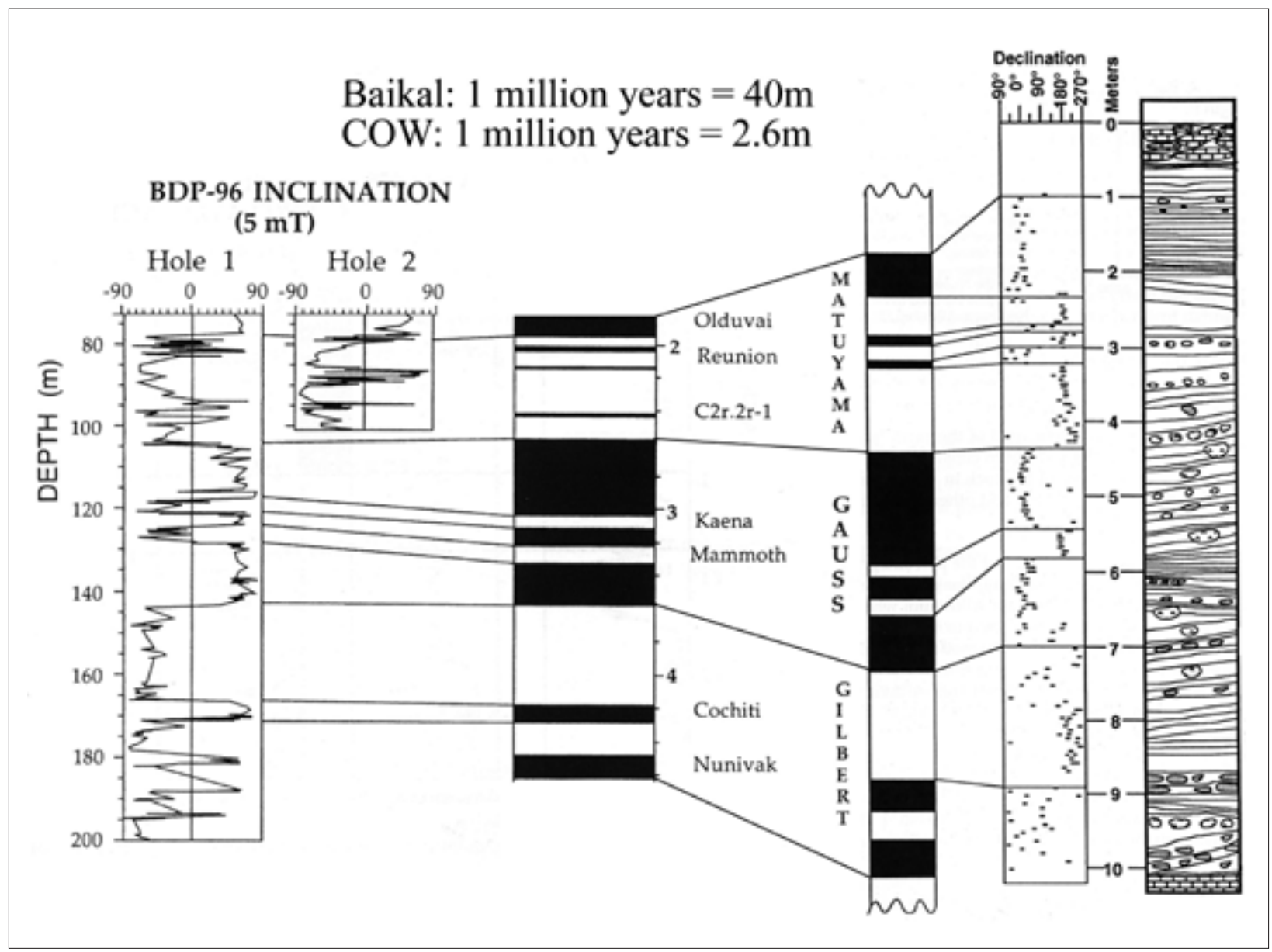

Fig. 3: Comparison of sedimentary records from Lake Baikal, Russia (3 columns on left), and Cave of the Winds, USA (3 columns on right). Baikal data used with permission from King and Peck, 2001. Cave of the Winds data used with permission from Luiszer, 1994. 


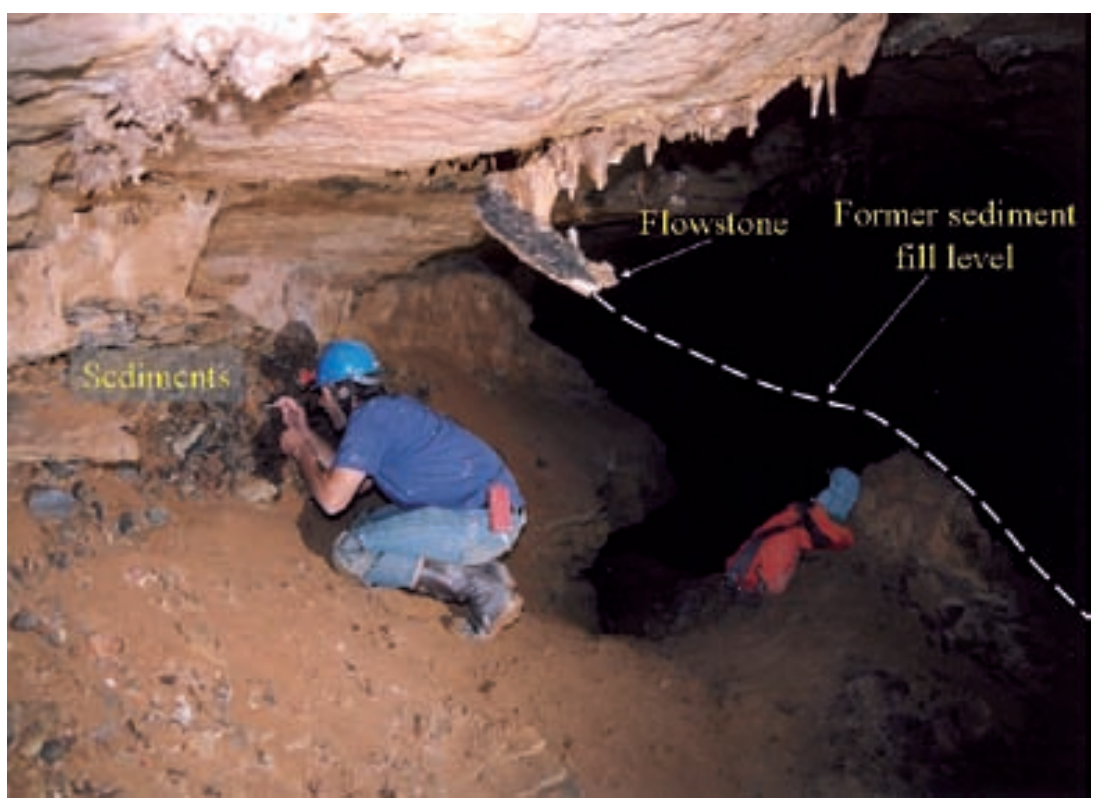

Fig. 4: Episodic infilling and removal of sediments is commonly observed in caves. In this section of Windy Mouth Cave (West Virginia, USA) a diamict was almost completely removed after being covered with flowstone. The conduit is presently dry.

surficial erosion. This is particularly germane for the fluvial deposits. Weathering and erosion of surface fluvial terraces is commonplace. In the cave, such materials may sit undisturbed for years. For example, in Xanadu Cave, Tennessee, USA, a pristine, non-indurated fluvial deposit that is greater than $780 \mathrm{ka}$ was sampled (Sasowsky, et al.,
1995). Although rare, in exceptional settings the quality of the cave record may approach that of lakes (Fig. 3). Conditions amenable to this are stable recharge configuration, diffuse recharge, minimal variation of discharge, and deep circulation. In Figure 3 two exceptional records are compared. The Lake Baikal record was constructed from cores taken on watercraft. In that setting, about 40 $\mathrm{m}$ of sediment accumulate in $1 \mathrm{Ma}$. In contrast, at Cave of the Winds the accumulation rate is slower by more than an order or magnitude.

In many settings caves appear to undergo episodic filling and excavation (Fig. 4). In certain cases this may be locally controlled by catastrophic storms (e.g. Doehring and Vierbuchen 1971). However, the presence of broadly similar deposits/incisions within many caves in a region supports the idea that cave clastic materials reflect regional paleoclimatic conditions. These deposits hold much information that will be revealed with continued advances in conceptual frameworks and improved laboratory methods.

\section{REFERENCES}

Anthony, D.M. \& D.E. Granger, 2004: A Late Tertiary origin for multilevel caves along the western escarpment of the Cumberland Plateau, Tennessee and Kentucky, established by cosmogenic ${ }^{26} \mathrm{Al}$ and ${ }^{10} \mathrm{Be}$. - Journal of Cave and Karst Studies, v. 66, no. 2, p. 46-55.

Bosák, P., P. Pruner, \& J. Kadlec, 2003: Magnetostratigraphy of cave sediments: Application and limits. - Studia Geophysica et Geodaetica, v. 47, p. 301-330.

Davies, W. E., 1951: Mechanics of cavern breakdown. National Speleological Society Bulletin, v. 13, p. 3643.

Doehring, D.O. \& R.C. Vierbuchen, 1971: Cave Development during a catastrophic storm in the Great Valley of Virginia. - Science, v. 174, no. 4016, p. 1327 1329.

Ford, D.C. \& P.W. Williams, 1989: Karst geomorphology and hydrology. - Unwin Hyman, London, 601 p.
Granger, D.E., D. Fabel, D. \& A.N. Palmer, 2001: Pliocene-Pleistocene incision of the Green River, Kentucky, determined from radioactive decay of cosmogenic ${ }^{26} \mathrm{Al}$ and ${ }^{10} \mathrm{Be}$ in Mammoth Cave sediments. - Geological Society of America Bulletin, v. 113; no. 7, p. 825-836.

Jackson, J.A. (ed.), 1997: Glossary of geology. - $4^{\text {th }}$ ed., American Geological Institute, Falls Church, Virginia, $769 \mathrm{p}$.

Jameson, R.A., 1991: Concept and classification of cave breakdown: An analysis of patterns of collapse in Friars Hole Cave System, West Virginia: - In, Kastning, E.H. and Kastning, K.M. (eds.), Appalachian Karst. - National Speleological Society, Huntsville, Alabama, USA, p. 35-44.

Jeannin, P.-Y., 2001: Modeling flow in phreatic and epiphreatic karst conduits in the Hölloch cave (Muotatal, Switzerland). - Water Resources Research, v. 37, no. 2 , p. 191-200. 
King, J. \& J. Peck, 2001: Use of paleomagnetism in studies of lake sediments: In: Last, W.M. \& J.P. Smol, (eds.), Tracking environmental change using lake sediments" Volume 1: Basin analysis, coring and chronological techniques. - Kluwer Academic Publishers, Dordrecht, p. 371-389.

Kukla, J. \& V. Ložek, 1958: K promlematice vyzkumu jeskynnich vyplni (To the problems of investigation of the cave deposits). - Českoslovensy Kras, v. 11, p. 19-83.

Loucks, R.G., 1999: Paleocave carbonate reservoirs: Origins, burial-depth modifications, spatial complexity, and reservoir implications. - AAPG Bulletin, v. 83; no. 11; p. 1795-1834.

Luiszer, F. G., 1994: Speleogenesis of Cave of the Winds, Manitou Springs, Colorado: In Sasowsky, I. D., and Palmer, M. V. (eds.) Breakthroughs in karst geomicrobiology and redox geochemistry (Special Publication 1). - Charles Town, West Virginia, Karst Waters Institute, p. 91-109.

May, M.T., K.W. Kuehn, C.G. Groves, C.G., \& J. Meiman, 2005: Karst geomorphology and environmental concerns of the Mammoth Cave region, Kentucky. - American Institute of Professional Geologists 2005 Annual Meeting Guidebook, Lexington, Kentucky, $44 \mathrm{p}$.

Milanovic, P. T., 1981: Karst Hydrogeology (translated from the Yugoslavian by J. J. Buhac). - Water Resources Publications, Littleton, Colorado, $434 \mathrm{p}$.

Polyak, V.J., W.C. McIntosh, N. Güven, N., \& P. Provencio, 1998: Age and origin of Carlsbad Cavern and related caves from ${ }^{40} \mathrm{Ar} /{ }^{39} \mathrm{Ar}$ of alunite. - Science, v. 279, no. 5358, p. 1919 - 1922

Sasowsky, I.D., 1998: Determining the age of what is not there. - Science, v. 279, no. 5358, p. 1874
Sasowsky, I. D. \& J.W. Mylroie (eds.), 2004: Studies of cave sediments: Physical and chemical recorders of climate change. - Kluwer Academic/Plenum Publishers, New York, $329 \mathrm{p}$.

Sasowsky, I. D., W.B. White, \& V.A. Schmidt, 1995: Determination of stream incision rate in the Appalachian Plateaus by using cave-sediment magnetostratigraphy. - Geology, v. 23, no. 5, p. 415-418.

Schroeder, J. \& D.C. Ford, 1983: Clastic sediments in Castleguard Cave, Columbia icefields, Canada. - Arctic and Alpine Research, v. 15, no. 4, p. 451-461.

Summerfield, M. A., \& N.J. Hulton, 1994: Natural controls of fluvial denudation rates in major world drainage basins. - Journal of Geophysical Research, v. 99(B7), p. 13,871-13,884.

Šušteršič, F., 2004: Cave sediments and denuded caverns in the Laški Ravnik, classical Karst of Slovenia: In: Sasowsky, I.D. and Mylroie, J.W. (eds.), Studies of cave sediments: Physical and chemical recorders of climate change. - Kluwer Academic/Plenum Publishers, New York, p. 123-134.

White, W. B., 1960: Termination of passages in Appalachian Caves as evidence for a shallow phreatic origin. - Bulletin of the National Speleological Society, v. 22 , no. 1, p. $43-53$.

White, W.B., 1988: Geomorphology and hydrology of karst terranes. - Oxford University Press, 464 p.

White, W.B. \& E.L. White, 2003: Gypsum wedging and cavern breakdown: Studies in the Mammoth Cave System Kentucky. - Journal of Cave and Karst Studies, v. 65 , no. 1 , p. $43-52$.

Wildberger, A. \& C. Preiswerk, 1997: Karst and caves of Switzerland. - SpeleoProjects, Basil, Switzerland, $208 \mathrm{p}$. 
